\title{
PENCANGKOKAN SECARA RADIASI ASAM AKRILAT PADA SELULOSA DENGAN KEBERADAAN METIL METAKRILAT
}

\section{RADIATION GRAFTING ACRYLIC ACID ONTO CELLULOSE IN THE PRESENT OF METHYL METHACRYLATE}

\author{
Meri Suhartini \\ Pusat Aplikasi Isotop Radiasi, BATAN \\ Jl. Lebak Bulus No.49, Jakarta \\ e-mail: mer@batan.go.id
}

Diterima 21 Januari 2015, diterima dalam bentuk perbaikan 27 Nopember 2015, disetujui 1 Desember 2015

\begin{abstract}
ABSTRAK
PENCANGKOKAN SECARA RADIASI ASAM AKRILAT PADA SELULOSA DENGAN KEBERADAAN METIL METAKRILAT. Dalam studi ini Selulosa pada jerami padi diisolasi secara kimia melalui tahap delipifikasi, demineralisasi, pulping dan delignifikasi. Modifikasi selulosa dilakukan menggunakan metode kopolimerisasi cangkok secara simultan dengan inisiator sinar gamma pada dosis 10 kGy; 20 kGy; 30 kGy; $40 \mathrm{kGy}$. Sebagai monomer digunakan asam akrilat (AA) dan metil metakrilat (MMA) dengan 2 macam variasi perbandingan konsentrasi. Studi ini bertujuan untuk mendapatkan selulosa yang mempunyai sifat fisik kimia tertentu yang dapat dipergunakan sebagai adsorben ion logam pada limbah cair bersuhu tinggi. Pada artikel ini pembahasan difokuskan lebih pada modifikasi selulosa menggunakan metode pencangkokan simultan secara iradiasi. Derajat pencangkokan dan rasio pengembangan sebelum dan setelah pencangkokan diobservasi. Karakterisasi sampel antara lain suhu degradasi dilakukan menggunakan differential scanning calorimetry (DSC) sementara analisis gugus fungsi dilakukan menggunakan Fourier Transform Infrared Spectroscopy (FTIR). Hasil studi menunjukkan bahwa dosis iradiasi optimal dicapai pada $30 \mathrm{kGy}$, dengan derajat pencangkokan sebesar 87,99\%. Keberhasilan kopolimerisasi ditunjukkan dengan munculnya puncak baru dari gugus fungsi $C=0$ pada bilangan gelombang $1705 \mathrm{~cm}^{-1}$, dan $C=C$ pada 1576 $\mathrm{Cm}^{-1}$. Suhu degradasi selulosa setelah pencangkokan dicapai pada $550{ }^{\circ} \mathrm{C}$ dan rasio pengembangan dalam air sebesar 117,04\%. Keberadaan metil metakrilat menurunkan rasio pengembangan kopolimer selulosa-AA dalam air sebesar 335,42\% dibandingkan kopolimer selulosa-AA tanpa MMA.
\end{abstract}

Kata kunci : Kopolimerisasi cangkok, selulosa, Asam Akrilat, Metil metakrilat

\begin{abstract}
RADIATION GRAFTING ACRYLIC ACID ONTO CELLULOSE IN THE PRESENT OF METHYL METHACRYLATE. In this study cellulose was isolated from rice straw using chemical methode, through delification, demineralization, pulping and delignification. Modification of cellulose was performed by simultaneously radiation grafting copolymerization methodeusing gamma-ray as initiator at various dose 10 , 20, 30 and $40 \mathrm{kGy}$. Acrylic acid (AA) and methyl methacrylate (MMA) were used as monomer with 2 variations of concentration. Aim of the study is to obtain cellulose which have certain physical chemical properties which can be used to adsorb metal ionsin the high-temperature liquid waste. This paper was focused on discussion ofcellulose modification by radiation grafting copolymerization methode. Grafting yields and swelling ratio were observed. Degradation temperature were analyzed using differential scanning calorimetry (DSC), while functional groups were observed using Fourier Transform Infrared Spectroscopy (FTIR). Results of the study showed that the optimal irradiation dose achieved at $30 \mathrm{kGy}$, with the grafting yield of $87.99 \%$. The success of graftingwas indicated by the appearance of a new peak of $C=O$ functional group on wave number $1705 \mathrm{~cm}^{-1}, C=C$ on $1576 \mathrm{~cm}^{-1}$. Characterization of grafted cellulose-AA-MMA showeddegradation temperature is $550{ }^{\circ} \mathrm{C}$ and the swelling ratio by $117.04 \%$. The present of methyl methacrylate on the sample decrease the swelling ratio in water by $335.42 \%$ compared to grafted celluloseAA copolymer without MMA.
\end{abstract}

Keywords: Graft copolymerization, cellulose, acrylic acid, methyl methacrylate 


\section{PENDAHULUAN}

$\mathrm{M}$ odifikasi selulosa dilakukan untuk memanfaatkan selulosa menjadi bahan yang memiliki berbagai manfaat dan meningkatkan nilai ekonomisnya. Selulosa memiliki banyak gugus hidroksil yang dapat dimodifikasi, penggunaan selulosa yang dimodifikasi antara lain sebagai material pemisah yang dapat dimanfaatkan dalam berbagai proses, antara lain proses adsorpsi, dialisis, elektrodialisis, osmosis, reverse osmosis serta mikrofiltrasi(1).

Kopolimerisasi cangkok menggunakan teknik radiasi merupakan salah satu metode dalam memodifikasi selulosa. Pada penelitian sebelumnya telah dilakukan kopolimerisasi cangkok secara kimia denganmerekayasa biopolimer jerami padi dengan menggunakan akrilamida sebagai monomer pencangkok dan N,N'metilenbisakrilamida (NBA) sebagai agen pengikat silang, menggunakan ammonium persulfat (APS) sebagai inisiator. Proses tersebut menghasilkan produk biopolimer dengan derajat pencangkokan sebesar $66,14 \%$ sampai $78,15 \%$ (2). Modifikasi selulosa dari jerami padi secara kimia dengan menggunakan asam nitrat $1 \mathrm{M}$, dapat meningkatkan penyerapan terhadap ion logam timbal (3). Kopolimerisasi cangkok dengan teknik iradiasi menggunakan sinar gamma memiliki beberapa kelebihan dibandingkan dengan cara kimia, fotokimia, enzim maupun induksi plasma (4). Kopolimer selulosa graft dengan poli (akrilikacid), N-vinil-2-pirolidon atau poliakrilamida yang bersifat hidrofilik, memiliki kapasitas penyerapan air yang tinggi (5). Untuk itu, mereka dapat digunakan sebagai penyerap cairan tubuh dalam aplikasi medis.(6). Pencangkokan monomer vinil larut dalam air pada serat kapas meningkatkan kemampuan penyerapan kelembaban yang dapat digunakan dalam kain, seperti pakaian dan pakaian olahraga (7). Selulosa-thiocarbamate-g-PAN memiliki aktivitas antimikroba yang tinggi. Selain itu, kopolimer selulosa graft diperoleh dengan mencangkok vinil monomer dengan kelompok-kelompok fungsional seperti akrilamida (8), asam akrilik (9), akrilonitril, dan asam 2-acrylamidomethylpropane sulfonat (10) telah digunakan dalam adsorpsi kontaminan berbahaya seperti ion logam berat atau zat warna pada larutan air(11).

Pada penelitian ini modifikasi selulosa dilakukan dengan cara kopolimerisasi cangkok menggunakan asam akrilat (AA) dan metil metakrilat (MMA) sebagai agen pencangkok. Sebagai inisiator dipergunakan iradiasi sinar gamma. Monomer dicangkokkan ke rantai selulosa melalui gugus hidroksil pada posisi C2, C3 dan C6. Gugus hidroksil pada C2 dan C3 adalah gugus hidroksil yang terikat pada atom karbon sekunder, sedangkan gugus hidroksil pada C6 terikat pada atom karbon primer, dimana kereaktifan gugus hidroksil primer dan sekunder ini berbeda. Dengan memilih monomer yang tepat, maka kekuatan mekanik dan stabilitas termal material berbasis selulosa yang dimodifikasi dengan teknik pencangkokan dapat ditingkatkan.

Keberhasilan modifikasi pada selulosa dilihat dari bertambahnya bobot selulosa setelah dimodifikasi. Karakterisasi kopolimer yang terbentuk meliputi gugus fungsi menggunakan Fourier Transform Infrared Spectroscopy (FTIR). Suhu degradasi menggunakan differential scanning calorimetry (DSC), dan derajat pengembangan (swelling capacity, \%) dalam air.

Proses kopolimerisasi dilakukan dengan metode iradiasi simultan menggunakan sumber iradiasi gamma dari isotop Co-60. Mekanisme reaksi yang terjadi secara garis besar ada 3 tahap, yaitu :

1. Inisiasi

Inisiasi adalah tahap pembentukan radikal bebas. Pada tahap ini selulosa, asam akrilat dan metil metakrilat diiradiasi secara simultan. Terjadi ketidakstabilan ikatan rangkap $\mathrm{C}=\mathrm{C}$ pada monomer asam akrilat dan metil metakrilat sehingga terbentuk radikal bebas. Pada selulosa terbentuk radikal bebas di gugus hidroksil pada posisi C6. Gugus hidroksil pada $\mathrm{C}_{6}$ terikat pada atom karbon primer. Selulosa dicangkok (grafting) oleh berbagai jenis monomer melalui gugus hidroksil pada posisi C6 (Gambar 1).

2. Propagasi

Tahap ini adalah perpanjangan rantai polimer. Radikal monomer akan menyerang unit monomer lainnya sehingga pada tahap ini berat molekul polimer menjadi besar. Asam akrilat dan metil metakrilat akan berekasi dengan radikal pada selulosa. Radikal selulosa yang tersisa akan diserang oleh monomer asam akrilat dan metil metakrilat begitu seterusnya sampai pada tahap terminasi (Gambar 2). 


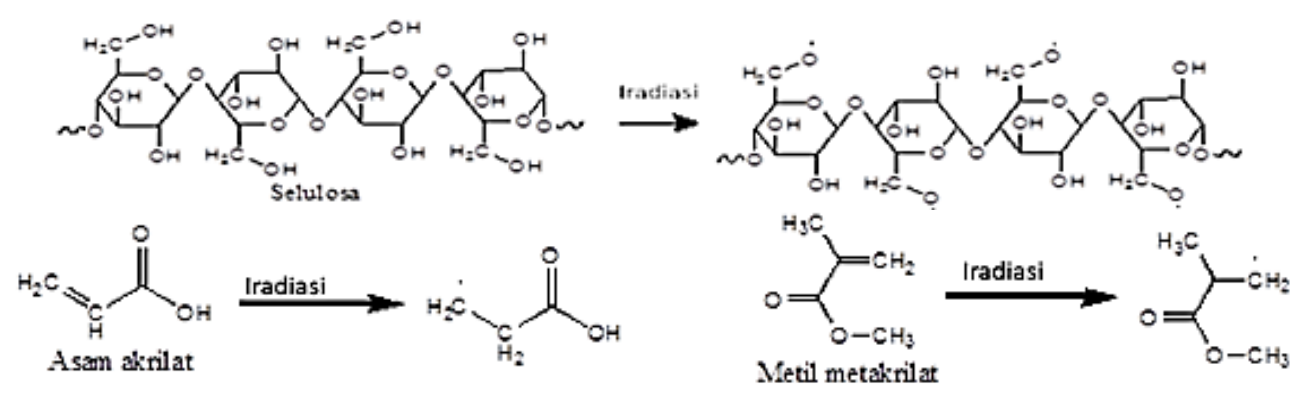

Gambar 1. Mekanisme reaksi tahap inisiasi.

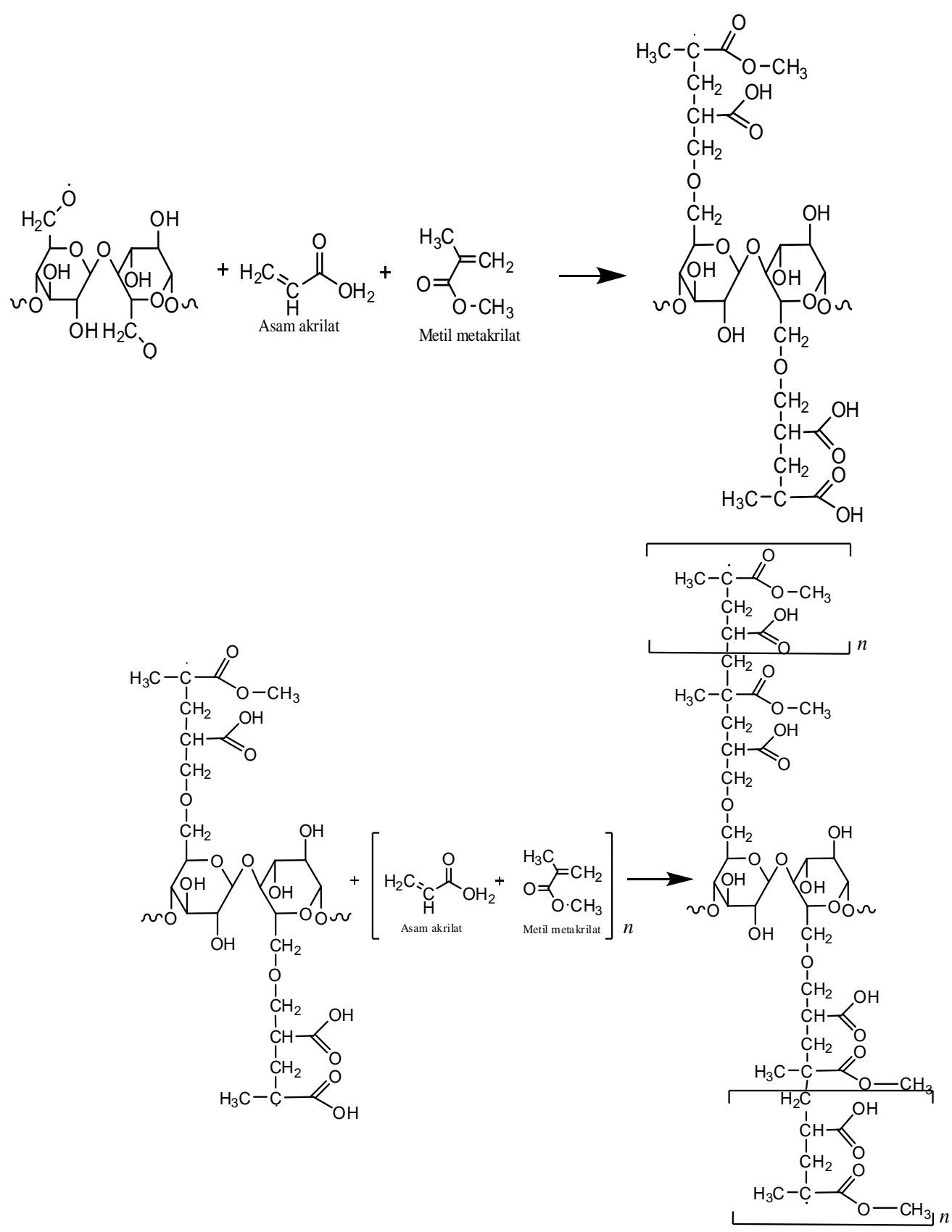

Gambar 2. Mekanisme reaksi tahap propagasi. 


\section{Terminasi}

Tahap ini adalah proses penghentian rantai polimer dengan cara penggabungan dua rantai polimer yang masih mengandung radikal, dikatakan terminasi karena sudah tidak ada lagi reaksi. Hasil akhir dari proses kopolimerisasi atau struktur kopolimer selulosa-AA-MMA (Gambar 3).

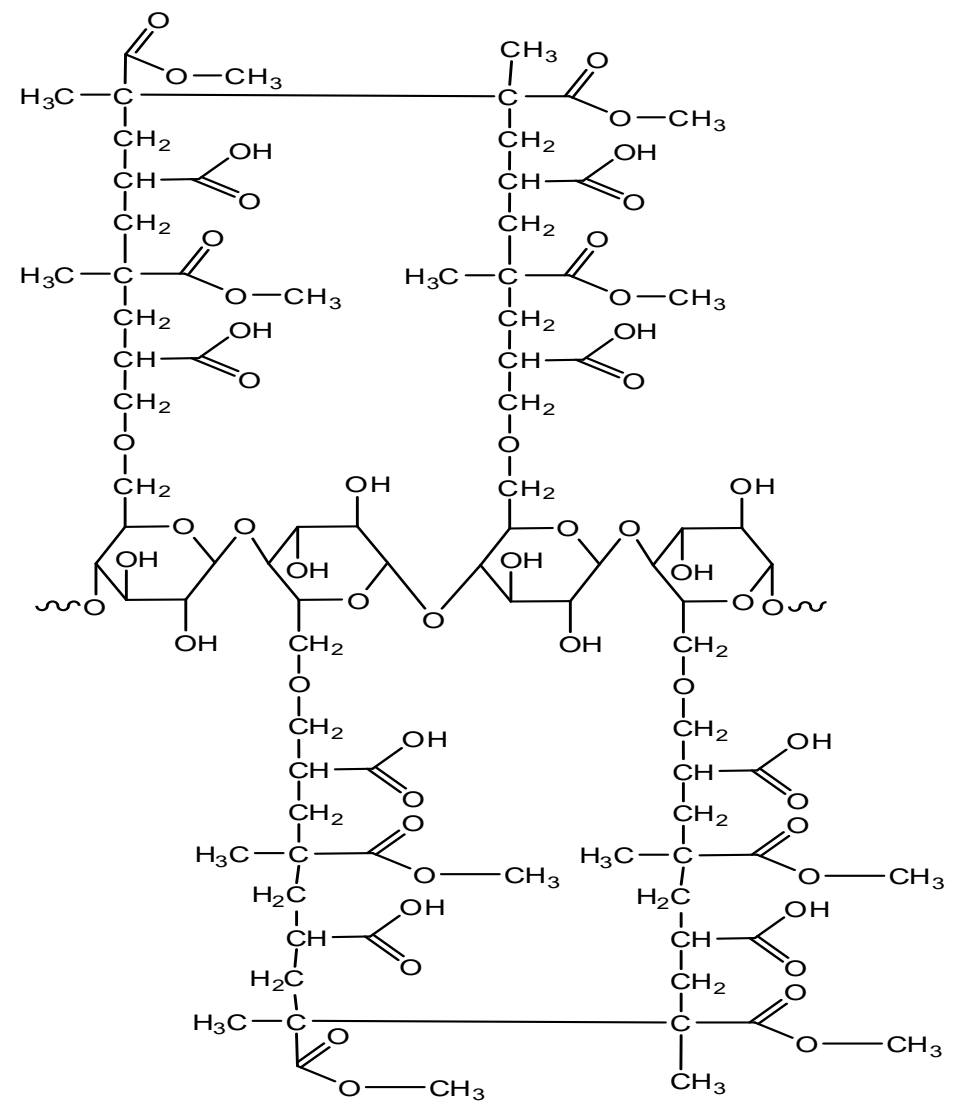

Gambar 3. Hasil tahap terminasi reaksi.

\section{METODOLOGI}

\section{Bahan}

Jerami padi, diperoleh dari Lahan Pertanian di Cigombong-Bogor, asam akrilat (Merck), metil metakrilat (Merck), toluena (Merck), metanol (Mallinckrodt), asam klorida (Merck), hidrogen peroksida (Merck), natrium hidroksida (Merck), asam sulfat (Merck), natrium karbonat (Merck), tembaga (II) sulfat, fenolftalein, metil merah, kalium bromida, alumina, akuades.

\section{Metode}

\section{Isolasi selulosa dari jerami padi}

Batang jerami padi kering direndam dalam pelarut campuran toluena-metanol (2:1) selama 48 jam disaring, ditambahkan asam klorida $3 \%$, dipanaskan selama 1 jam pada suhu $70^{\circ} \mathrm{C}$, kemudian disaring kembali dan dicuci dengan akuades hingga netral. Selanjutnya ditambahkan natrium hidroksida $20 \%$, dipanaskan selama 3 jam pada suhu $80^{\circ} \mathrm{C}$, disaring dan dicuci dengan akuades. Selulosa yang diperoleh kemudian diberi hidrogen peroksida $1,5 \% \mathrm{pH} 12$ dan dipanaskan selama 3 jam pada suhu $80^{\circ} \mathrm{C}$, kemudian disaring dan dicuci dengan akuades hingga netral. Pengeringan dilakukan dalam oven pada suhu $70^{\circ} \mathrm{C}$.

\section{Pencangkokan}

Pada pencangkokan dibuat dua macam kopolimer. Kopolimer A dilakukan dengan mencampur selulosa sebanyak 5 gram dengan $5 \%$ metil metakrilat kemudian ditambahkan $95 \%$ asam akrilat. Kopolimer B dilakukan 
dengan mencampur selulosa sebanyak 5 gram dengan 1\% metil metakrilat kemudian ditambahkan 20\% asam akrilat. Kedua formula tersebut kemudian diiradiasi dengan sinar gamma pada dosis 10, 20, 30 dan $40 \mathrm{kGy}$ dengan laju dosis $5 \mathrm{kGy} / \mathrm{jam}$. Kopolimer yang dihasilkan dicuci dengan akuades pada suhu $70{ }^{\circ} \mathrm{C}$ untuk menghilangkan homopolimer yang terbentuk, maupun monomer yang tersisa, kemudian dikeringkan didalam oven pada suhu $80^{\circ} \mathrm{C}$ hingga bobot tetap.

Derajat pencangkokkan dihitung dengan menggunakan rumus sebagai berikut:

$$
\text { Derajat pencangkokan }=\left(W_{1}-W_{0}\right) / W_{0} \times 100 \%
$$

Keterangan:

$W_{0}=$ bobot kering selulosa sebelum pencangkokan (gram).

$W_{1}=$ bobot kering selulosa setelah pencangkokan (gram).

\section{Karakterisasi Kopolimer}

\section{Analisis gugus fungsi dengan Fourier Transform Infrared Spectroscopy (FTIR)}

Spektrum infra merah selulosa, selulosa cangkok dan selulosa cangkok terikat silang direkam melalui spektrometer IR Prestige 21 Shimadzu pada bilangan gelombang $4000-400 \mathrm{~cm}^{-1}$ dengan scanning 20 kali per contoh.

\section{Analisis suhu degradasi dengan differential scanning calorimetry (DSC)}

Penentuan DSC dilakukan menggunakan DSC-60 Shimadzu. Pengukuran dilakukan pada kisaran suhu $30-600{ }^{\circ} \mathrm{C}$ dengan laju kenaikan suhu $10^{\circ} \mathrm{C} /$ menit. Termogram sesudah pencangkokan dibandingkan dengan termogram selulosa awal.

\section{Penentuan derajat pengembangan ( swelling capacity, \%S) dalam air}

Sejumlah lebih kurang 0,05 gram kopolimer dimasukkan ke dalam wadah gelas plastik, ditambahkan 50 $\mathrm{mL}$ akuades, kemudian didiamkan selama 24 jam. Selanjutnya kopolimer disaring dengan saringan stainless stell 120 mesh, ditiriskan selama 30 menit dan ditimbang. Derajat pengembangan (swelling capacity, \%S) dalam air dihitung dengan menggunakan rumus sebagai berikut:

$$
\text { Derajat pengembangan }(\% S)=\left(W_{2}-W_{1}\right) / W_{1} \times 100 \%
$$

Keterangan:

$W_{1}=$ bobot selulosa tercangkok sebelum perendaman dalam air.

$W_{2}=$ bobot selulosa tercangkok setelah perendaman dalam air selama 24 jam.

\section{HASIL DAN PEMBAHASAN}

Pada penelitian ini selulosa pada jerami padi diisolasi untuk menghilangkan lignin yang akan menghambat proses pencangkokan karena lignin bersifat scavenger ${ }^{(12)}$. Isolasi dilakukan secara kimia melalui tahap delipifikasi, demineralisasi, pulping dan delignifikasi Isolasi selulosa dari jerami yang telah dilakukan menghasilkan randemen $26,33 \%$, dengan kadar selulosa $89,71 \%$ dan sisa lignin 0,99 . Semakin tinggi kadar selulosa yang terkandung dalam pulp, maka semakin baik kualitas pulp. Kadar selulosa dan sisa lignin tersebut menunjukkan kualitas pulp yang baik dan memenuhi persyaratan untuk dibuat kopolimer yaitu kadar selulosa lebih dari 40\% dan kadar lignin kurang dari 10\% (13).

Keberhasilan kopolimerisasi cangkok ditentukan oleh seberapa banyak monomer asam akrilat dan metil metakrilat yang tercangkok pada selulosa seiring dengan bertambahnya dosis iradiasi. Keberhasilan tersebut dinyatakan sebagai derajat pencangkokan (\% grafting). Grafik hubungan derajat pencangkokan dengan dosis iradiasi pada kopolimer selulosa-AA-MMA pada dua konsentrasi monomer yang berbeda disajikan pada Gambar 4. 


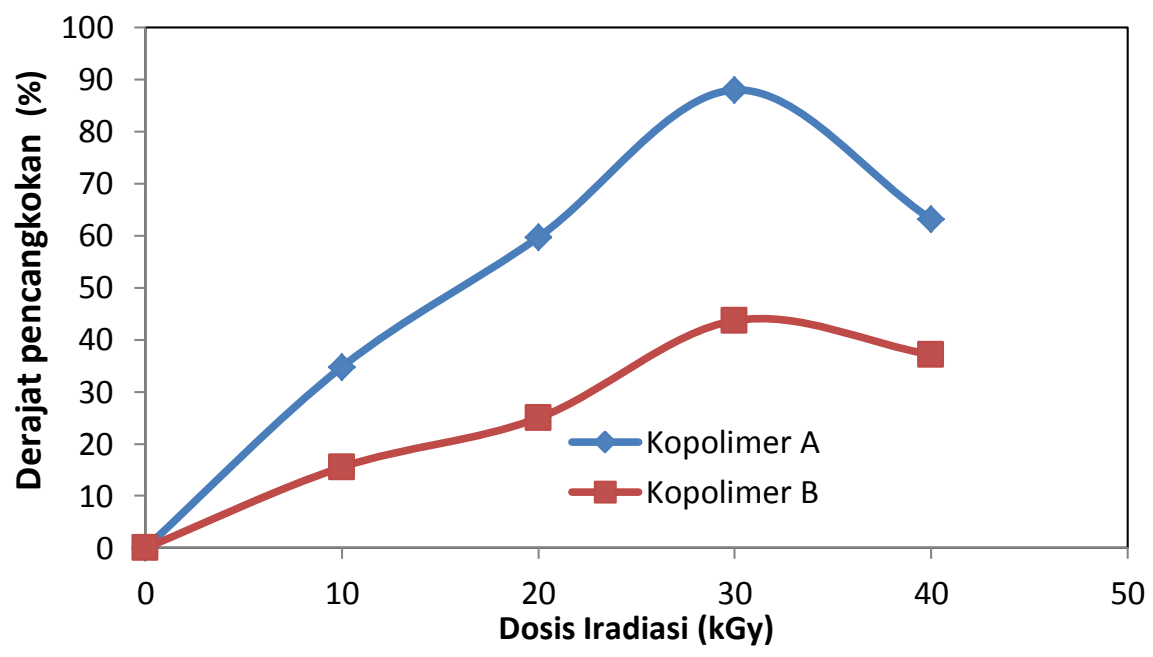

Gambar 4. Grafik hubungan antara dosis iradiasi dengan derajat pencangkokan pada kopolimer selulosa-AAMMA.

Pada gambar 4 terlihat bahwa sampai dosis $30 \mathrm{kGy}$, semakin besar dosis iradiasi menyebabkan semakin bertambah derajat pencangkokan. Pada dosis diatas $30 \mathrm{kGy}$ derajat pencangkokan menurun bersama bertambahnya dosis radiasi. Peningkatan derajat pencangkokan yang terjadi sampai dosis $30 \mathrm{kGy}$ disebabkan semakin banyaknya jumlah radikal bebas yang terbentuk, dapat menginisiasi kopolimerisasi pencangkokan. Sementara pada dosis yang lebih tinggi dari $30 \mathrm{kGy}$, jumlah radikal bebas yang semakin banyak menyebabkan meningkatnya reaksi homopolimerisasi yang disebabkan adanya transfer radikal ke molekul monomer. Selain itu pada dosis yang tinggi dapat terjadi degradasi kerangka selulosa akibat reaksi pemutusan rantai, karena selulosa termasuk ke dalam tipe polimer yang degradable terhadap radiasi (14,15).

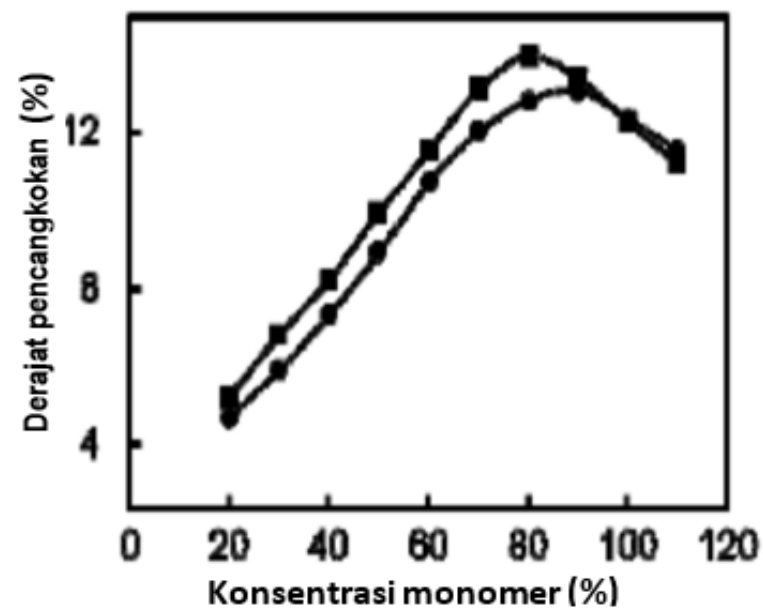

Gambar 5. Grafik hubungan antara derajatpencangkokanpada Jute fiber yang dicangkok dengan Metil akrilat

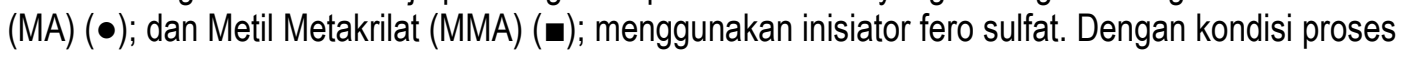
: $\mathrm{K}_{2} \mathrm{~S}_{2} \mathrm{O} \mathrm{O}, 1.0 \% ; \mathrm{FeSO}_{4}, 1.0 \%$; suhu $50^{\circ} \mathrm{C}$; waktu 60 menit, rasio fiber-liquor $1: 50$ (16).

Derajat pencangkokan yang terbentuk pada kopolimer A pada dosis $30 \mathrm{kGy}$ adalah $87,99 \%$, sedangkan pada kopolimer B adalah 43,67\%. Derajat pencangkokan pada kopolimer A menghasilkan derajat pencangkokan yang lebih besar dibandingkan dengan kopolimer B. Hal ini disebabkan karena konsentrasi monomer-pada formula A mengandung asam akrilat dan metil metakrilat yang lebih tinggi dibandingkan pada formula $B$. Dengan semakin tinggi konsentrasi monomer yang digunakan maka gugus fungsi dari monomer yang terikat pada rantai 
selulosa akan semakin banyak pada dosis iradiasi yang sama. Sedangkan pada Gambar 5, dapat dilihat Grafik hubungan antara derajat pencangkokan pada Jute fiber yang dipencangkokan dengan Metil akrilat dan Metil Metakrilat menggunakan inisiator fero sulfat. Dari gambar tersebut dapat dilihat bahwa derajat pencangkokan mencapai maksimum pada konsentrasi monomer yang digunakan $80 \%$, pada kondisi tersebut pencangkokan dengan monomer MMA mencapai derajat pencangkokan 14\%, sedangkan pencangkokan dengan monomer MA mencapai derajat pencangkokan 13\%. Dari penelitian secara kimia (konvensional) dan secara radiasi tersebut dapat disimpulkan bahwa pencangkokan dengan teknik radiasi menghasilkan derajat pencangkokan yang relatif lebih baik bila dibandingkan dengan pencangkokan menggunakan metode konvensional.

\section{Analisis Gugus Fungsi Dengan FTIR}

Pengujian gugus fungsi pada kopolimer bertujuan untuk mengidentifikasi adanya perubahan gugus fungsi setelah proses kopolimerisasi cangkok. Analisis gugus fungsi pada penelitian ini dilakukan pada kopolimer selulosa-AA-MMA dengan derajat pencangkokan tertinggi, dari kopolimer A dan dari kopolimer B. Pada Gambar 6 dan Tabel 1 dapat dilihat terbentuknya kopolimer cangkok ditandai dengan munculnya puncak (peak) baru yang tidak terdapat pada spektra selulosa hasil isolasi jerami padi. Monomer asam akrilat merupakan senyawa asam karboksilat, dimana pada golongan senyawa asam karboksilat akan muncul puncak dari gugus fungsi $\mathrm{C}=$ 0 pada rentang bilangan gelombang $1820-1660 \mathrm{~cm}^{-1}$. Monomer metil metakrilat merupakan senyawa ester, dimana pada golongan senyawa ester akan muncul puncak dari gugus fungsi $\mathrm{C}$ - $\mathrm{O}$ pada rentang bilangan gelombang 1300 - $1000 \mathrm{~cm}^{-1}$. Spektra FTIR kopolimer selulosa-AA-MMA menunjukkan telah terjadinya pencangkokan asam akrilat dan metil metakrilat karena muncul puncak baru dari gugus fungsi $\mathrm{C}=\mathrm{O}$ pada bilangan gelombang $1705 \mathrm{~cm}^{-1}$ pada kopolimer A dan $1718 \mathrm{~cm}^{-1}$ pada kopolimer $\mathrm{B}$. Pada asam akrilat hal ini didukung dengan adanya gugus $\mathrm{OH}$ (asam akrilat merupakan asam karboksilat) pada bilangan gelombang 3015 $\mathrm{cm}^{-1}$ pada kopolimer $A$ dan $3481 \mathrm{~cm}^{-1}$ pada $B$, sedangkan pada metil metakrilat hal ini didukung dengan adanya gugus $C$ - $O$ (metil metakrilat merupakan ester) pada bilangan gelombang $1343 \mathrm{~cm}^{-1}$ pada kopolimer A dan 1142 $\mathrm{cm}^{-1}$ pada kopolimer B. Terbentuknya kopolimer cangkok juga ditunjukkan dengan adanya puncak dari gugus fungsi $C=C$ yang berasal dari asam akrilat maupun metil metakrilat pada bilangan gelombang $1576 \mathrm{~cm}^{-1}$ pada kopolimer A dan $1431 \mathrm{~cm}^{-1}$ pada B. Pada gugus fungsi $\mathrm{CH}$ alifatik pada bilangan gelombang $2766 \mathrm{~cm}^{-1}$ pada kopolimer A dan $2889 \mathrm{~cm}^{-1}$ pada B selain berasal dari monomer-monomer asam akrilat dan metil metakrilat yang digunakan dalam reaksi pencangkokan juga dapat berasal dari selulosa sedangkan gugus fungsi $\mathrm{CH}$ aromatik pada bilangan gelombang $3611 \mathrm{~cm}^{-1}$ pada kopolimer A dan $3481 \mathrm{~cm}^{-1}$ pada kopolimer B hanya berasal dari kerangka utama pencangkokan yaitu selulosa.

Tabel 1. Gugus fungsi dan bilangan gelombang selulosa dan kopolimer selulosa-AA-MMA pada spektrum FTIR.

\begin{tabular}{lccc}
\hline \multirow{2}{*}{ Gugus fungsi } & \multicolumn{2}{c}{$\begin{array}{c}\text { Bilangan gelombang kopolimer } \\
\text { selulosa-AA-MMA }\left(\mathrm{cm}^{-1}\right)\end{array}$} & $\begin{array}{c}\text { Bilangan } \\
\text { gelombang }\end{array}$ \\
\cline { 2 - 3 } & Kopolimer A & Kopolimer B & selulosa $\left(\mathrm{cm}^{-1}\right)$ \\
\hline$-\mathrm{OH}$ & 3015 & 3481 & 3307 \\
\hline $\mathrm{C}-\mathrm{O}$ & 1343 & 1142 & 1008 \\
\hline $\mathrm{CH}$ alifatik & 2766 & 2889 & 2892 \\
\hline $\mathrm{CH}$ aromatik & 3611 & 3481 & 3613 \\
\hline $\mathrm{C}=\mathrm{C}$ & 1576 & 1431 & - \\
\hline $\mathrm{C}=\mathrm{O}$ & 1705 & 1718 & - \\
\hline
\end{tabular}




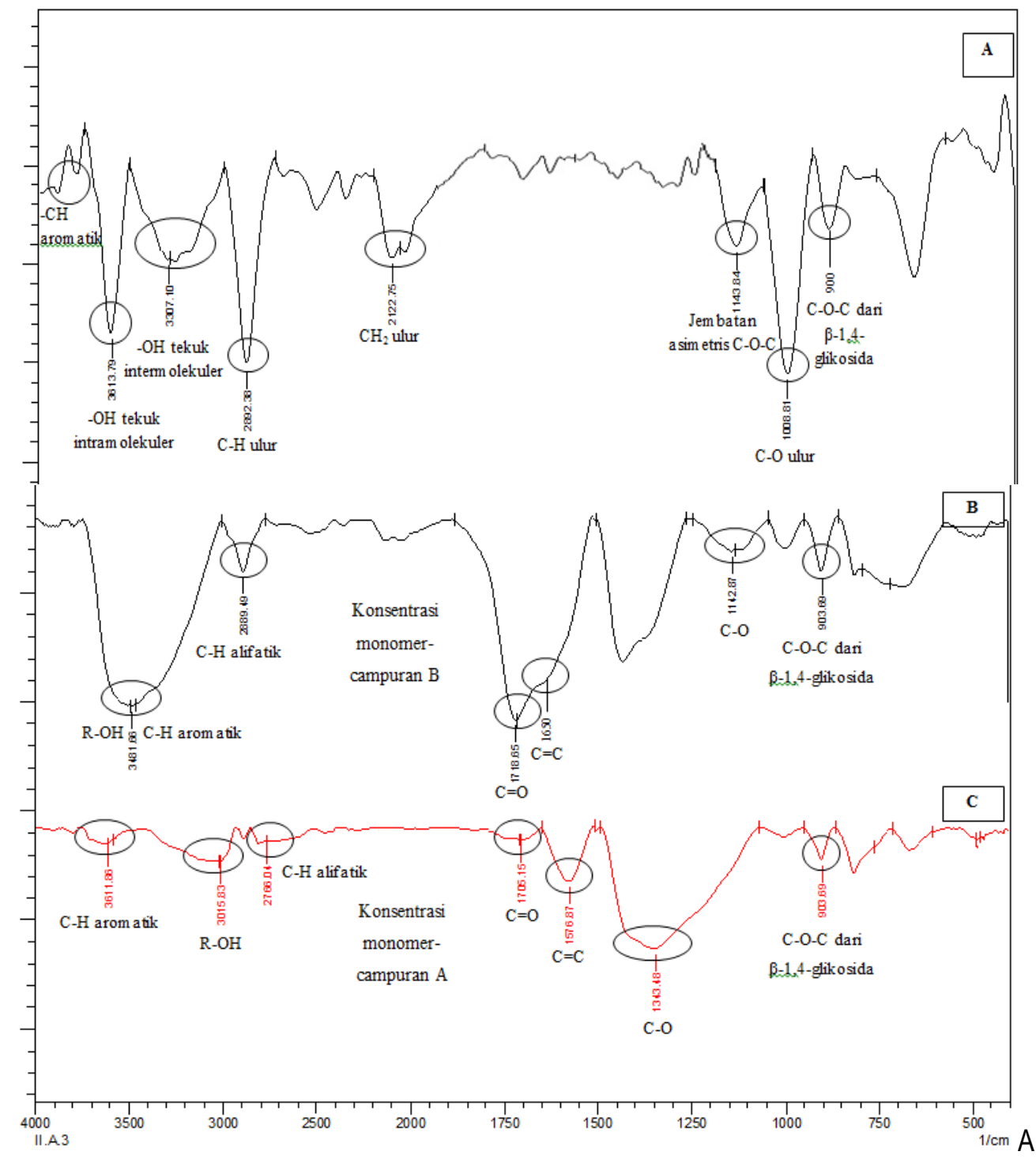

Gambar 6. A Spektrum FTIR isolat jerami padi, B. Spektrum FTIR kopolimer B, C. Spektrum FTIR kopolimer A.

\section{Analisis Ketahanan Panas}

Analisis menggunakan DSC dilakukan untuk studi kuantitatif transisi termal dari polimer, bertujuan untuk mengetahui suhu degradasi kopolimer. Analisis suhu degradasi dilakukan pada kopolimer selulosa-AA-MMA dengan derajat pencangkokan tertinggi. Termogram DSC dari selulosa hasil isolasi jerami padi dan kopolimer selulosa-AA-MMA disajikan pada Gambar 7. Pada termogram tampak pergeseran puncak yang sangat nyata antara selulosa hasil isolasi jerami padi dan kopolimer selulosa-AA-MMA. Pada termogram selulosa terdapat dua titik puncak eksoterm, yaitu pada suhu $350^{\circ} \mathrm{C}$ dan $462,5^{\circ} \mathrm{C}$. Puncak eksoterm yang diamati adalah pada kisaran suhu $400-600{ }^{\circ} \mathrm{C}$ karena menggambarkan suhu degradasi. Suhu degradasi dari selulosa hasil isolasi jerami padi sekitar $462,5^{\circ} \mathrm{C}$, sedangkan pada kopolimer $\mathrm{A}$ dan B berturut-turut adalah $550^{\circ} \mathrm{C}$ dan $535^{\circ} \mathrm{C}$ sehingga dapat disimpulkan bahwa kopolimer selulosa-AA-MMA memiliki suhu degradasi yang lebih tinggi dibandingkan selulosa hasil isolasi karena dibutuhkan panas yang lebih tinggi untuk mendegradasi kopolimer tersebut. Semakin meningkatnya hasil pencangkokan maka meningkat pula ketahanan panasnya yang ditandai dengan peningkatan suhu degradasi pada kopolimer tersebut. 


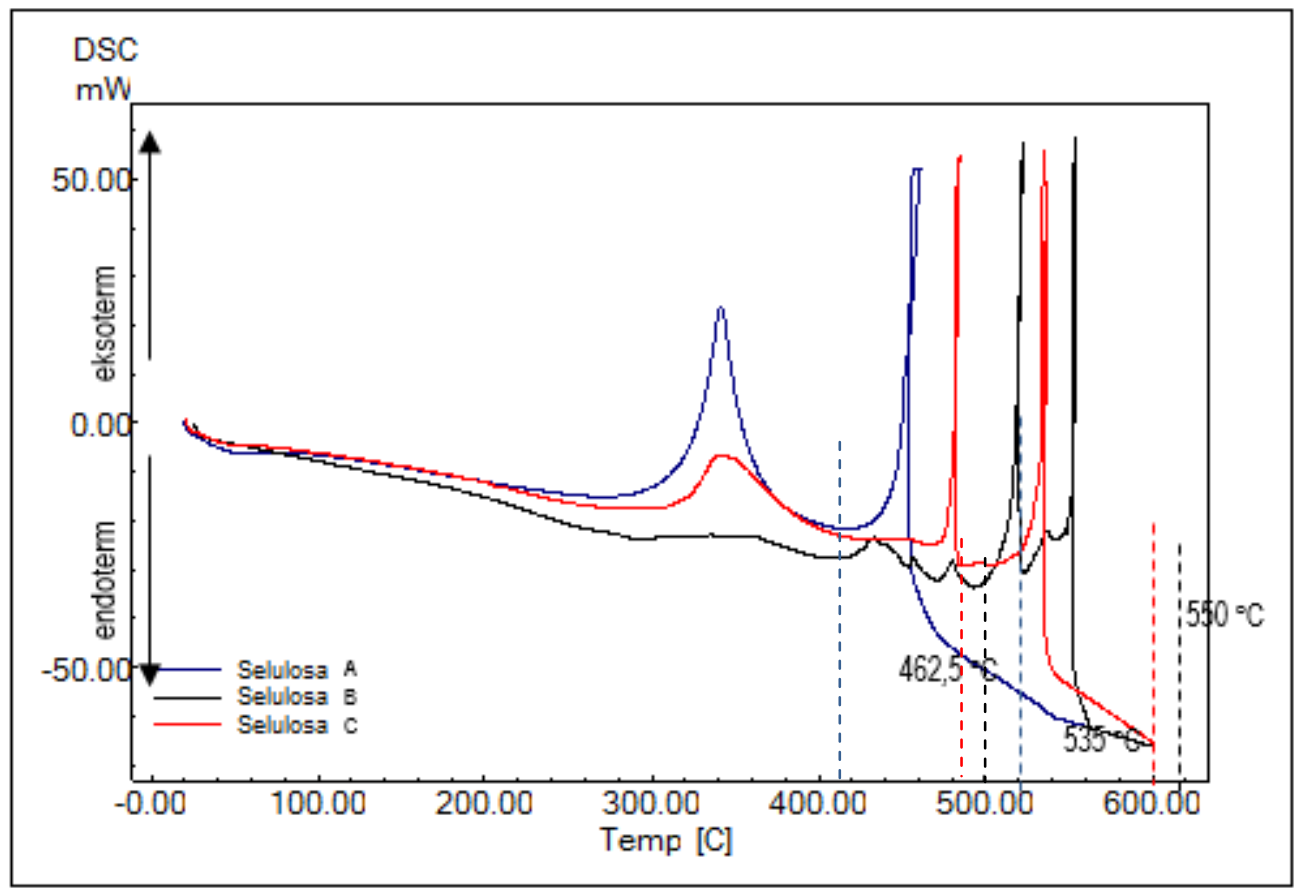

Gambar 7. A. Termogram DSC isolat jerami padi, B. Termogram DSC kopolimer A, C. Termogram DSC kopolimer B.

\section{Penentuan Derajat Pengembangan (Swelling Capacity) Dalam Air}

Sifat hidrofilik selulosa adalah karena adanya gugus-gugus $\mathrm{OH}$ yang terorientasi ke arah luar heliks, dapat mengikat molekul air dan menyebabkan pengembangan (swelling) bila direndam dalam air. Pencangkokan MMA mengurangi pengembangan selulosa di dalam air karena sebagian gugus $\mathrm{OH}$ tersubstitusi oleh rantai monomer MMA. Pengujian penyerapan air pada kopolimer selulosa-AA-MMA dilakukan dengan perendaman selama 24 jam dalam air. Hal ini dilakukan untuk mengetahui ada atau tidaknya peningkatan pengembangan selulosa sebelum dan sesudah modifikasi. Pada pengujian derajat pengembangan terhadap selulosa hasil isolasi dari jerami padi diperoleh derajat pengembangan sebesar $544,49 \%$ dan bila dibandingkan dengan hasil yang diperoleh pada kopolimer selulosa-AA-MMA terjadi penurunan nilai yang signifikan.

Derajat pengembangan kopolimer A pada dosis 10, 20, 30 dan 40 kGy secara berturut-turut adalah $159,94 \%, 130,96 \%, 117,04 \%$ dan $135,70 \%$, sedangkan pada kopolimer B secara berturut-turut adalah $425,87 \%$, $345,28 \%, 164,10 \%$ dan $301,88 \%$. Pada Gambar 8 dapat dilihat bahwa derajat pengembangan terendah berada pada kopolimer dengan dosis iradiasi sebesar $30 \mathrm{kGy}$. Terjadi penurunan kapasitas pengembangan baik pada kopolimer A maupun B hal ini menunjukkan adanya pengurangan gugus hidroksil pada rantai selulosa. Dengan adanya pencangkokan, sebagian besar gugus hidroksil tersubstitusi oleh monomer-monomer pencangkok, selain itu dengan adanya subtitusi metil metakrilat dapat meningkatkan kerapatan ikatan antar molekul pada kopolimer yang terbentuk, sehingga menyebabkan absorbsi air menurun. Semakin besar dosis iradiasi semakin rendah pula derajat pengembangannya dalam air, tetapi pada dosis iradiasi sebesar $40 \mathrm{kGy}$ menunjukkan peningkatan kapasitas swelling dibandingkan pencangkokan pada dosis $30 \mathrm{kGy}$, kopolimer pada dosis iradiasi $40 \mathrm{kGy}$ mempunyai kerapatan ikatan antar molekul yang lebih besar, hal ini didukung dengan data derajat pencangkokan pada dosis $40 \mathrm{kGy}$ yang lebih rendah dari derajat pencangkokan kopolimer pada dosis $30 \mathrm{kGy}$. Berdasarkan gambar juga dapat dilihat bahwa kopolimer B memiliki derajat pengembangan yang lebih besar dibandingkan kopolimer $\mathrm{A}$, hal ini karena metil metakrilat yang tercangkok pada selulosa maupun yang terhomopolimerisasi bersifat keras yang dapat menghambat terjadinya pengembangan kopolimer selulosa - AA bila direndam dalam air. Asam akrilat yang tercangkok pada selulosa tanpa penambahan metil metakrilat mempunyai derajat pengembangan $393,79 \%{ }^{(17)}$ dimana hal ini akan mengganggu secara teknis bila kopolimer tersebut akan 
dipergunakan sebagai adsorben ion logam berat atau zat warna pada limbah cair. Penambahan metil metakrilat menurunkan rasio pengembangan kopolimer dalam air sebesar 335,43\%.

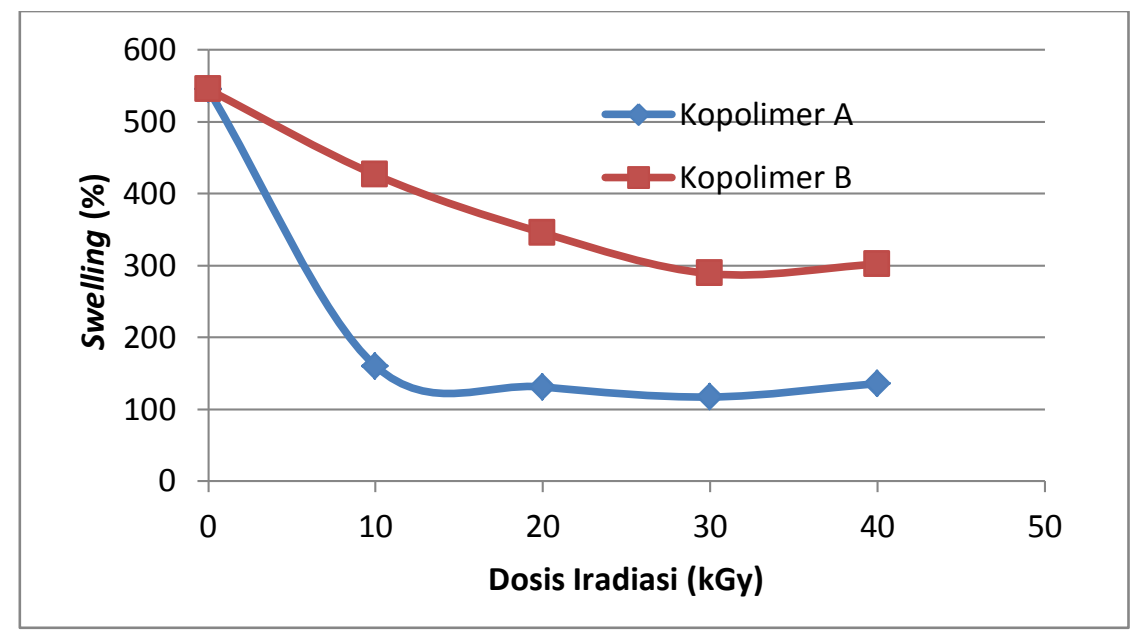

Gambar 8. Grafik hubungan antara dosis iradiasi dengan swelling capacity pada kopolimer cangkok selulosa-AAMMA.

\section{KESIMPULAN}

Isolasi selulosa dari jerami yang telah dilakukan menghasilkan randemen $26,33 \%$, dengan kadar selulosa $89,71 \%$ dan sisa lignin $0,99 \%$. Pencangkokan asam akrilat pada selulosa hasil isolasi dengan keberadaan metilmetakrilat menunjukkan hasil derajat pencangkokan $87,99 \%$ untuk formula $A$ dan $43,67 \%$ untuk formula B. Hasil tersebut diperoleh pada dosis 30Gy. Kopolimer dengan derajat pencangkokan 87,99\% mempunyai derajat pengembangan yang lebih kecil dan suhu degradasi yang lebih tinggi dibandingkan kopolimer dengan derajat pencangkokan $43,67 \%$ yang mempunyai derajat pengembangan lebih tinggi dan suhu degradasi lebih rendah. Keberhasilan kopolimerisasi cangkok ditunjukkan dengan munculnya puncak baru dari gugus fungsi $\mathrm{C}=0$ pada bilangan gelombang $1705 \mathrm{~cm}^{-1}, C=C$ pada $1576 \mathrm{~cm}^{-1}$.

\section{UCAPAN TERIMA KASIH}

Penulis mengucapkan terima kasih kepada Sdr. Cahyono (PATIR-BATAN) atas bantuannya mengiradiasi sampel selulosa-AA-MMA dan Drs. Erizal PU atas bantuan analisis FTIR. Terimakasih khusus kepada Sdr. Ayu Miranti. (Universitas Pancasila) atas bantuannya sehingga penelitian ini dapat berjalan seperti yang diharapkan.

\section{DAFTAR PUSTAKA}

1. A. BHATTACHARYA, B. MISRA, Grafting: a versatile means to modify polymer. Progress in Polymer Science 29 (2004) 767-814.

2. H. PURWANINGSIH, Rekayasa biopolimer jerami padi dengan teknik kopolimerisasi cangkok dan taut silang. Valensi 2(4) (2012) 489-500.

3. I. SAFRIANTI, W. NELLY, A.Z. TITIN, Adsorpsi timbal (II) oleh selulosa jerami padi teraktivasi asam nitrat: pengaruh $\mathrm{pH}$ dan waktu kontak. JKK. 1(1) (2010) 1-7.

4. L. WOJNAROVITS, C.S. FOLDVARY, E. TAKACS, Radiation-induced grafting of cellulose for absorption of hazardous water pollutant. Radiation Physics and Chemistry. 79 (2010) 848-862. 
5. I.W. NOORDERGRAAF, H.J. HEERESB, L.P.B.M. JANSSEN. Graft copolymerization of acrylic acid to cassava starch-Evaluation of the influences of process parameters by an experimental design method, Carbohydrate Polymers 90 (2012) 1522-1529.

6. T. TOLEDANO-THOMPSON, M.I. LORI'A-BASTARRACHEA, M.J. AGUILAR-VEGA, Characterization of henequen cellulose microfibers treated with an epoxide and grafted with poly(acrylic acid). J. Carb. Polym. 62 (2005) 67-73.

7. M.D. IBRAHIM, H. MONDAL, Y. URAKI, M. UBUKATA, K. ITOYAMA,Graft polymerization of vinyl monomers onto cotton fibres pretreated with amines. Cellulose J. 15 (2008) 581-592.

8. N. BIC,AK, D.C. SHERRINGTON, B.F. SENKAL, Graft copolymer of acrylamide onto cellulose as mercury selective sorbent. React. Funct. Polym. 41 (1999) 69-76.

9. C. AVUSS.,GU"RDAG“G., M. YAS,AR, K. GU"C,LU", M.A. GU"RKAYNAK, The competitive heavy metal removal by hydroxyethyl cellulose-g-poly(acrylic acid) copolymer and its sodium salt: The effect of copper content on the adsorption capacity. Polym. Bull. 57 (2006) 445-456.

10. O.H. WEN, S.I. KURODA, H.KUBOTA, Temperature-responsive character of acrylic acid and Nisopropylacrylamide binary monomers-grafted celluloses. Eur. Polym. J., 37 (2001) 807-813.

11. D.W. O'CONNELL, C. BIRKINSHAW, T.F. O'DWYER, A modified cellulose adsorbent for the removal of nickel(II) from aqueous solutions. J. Chem. Technol. Biotechnol. 81(2006) 1820-1828.

12. V.S. IVANOV, Radiation chemistry of polymers. Utrecht The Netherland: VCB BV, (1992) 7,127-8, 131, 149, 484.

13. W. ANDRIYANTI, SUYANTI, NGASIFUDIN, "Pembuatan dan karakterisasi polimer superabsorben dari ampas tebu". Prosiding Pertemuan dan Presentasi IImiah Teknologi Akselerator dan Aplikasinya, Yogyakarta 13 (2012) 3.

14. A. CHARLESBY, Atomic Radiation and Polymers, Pergamon Press, London (1960).

15. DEEPAK PATHANIA AND REENA SHARMA, Synthesis And Characterization Of Graft Copolymers Of Methacrylic Acid Onto Gelatinized Potato Starch Using Chromic Acid Initiator In Presence Of Air, Adv. Mat. Lett. 3(2), (2012) 136-142.

16. M.D. IBRAHIM, H. MONDAL, Grafting of methyl acrylate and methyl methacrylate onto jute fiber: physicochemical characteristics of the grafted jute. Journal of Engineered Fibers and Fabrics. 8 (2013) 3.

17. RAHMAWATI, Kopolimerisasi cangkok Asam akrilat pada selulosa jerami padi dengan teknik pra-iradiasi: karakterisasi dan aplikasinya sebagai penukar ion, Thesis, Departemen Kimia, FMIPA-UI, Depok (2013). 